\title{
Effect of inoculation of the plant root system by the endophyte Cylindrocarpon magnusianum on plant performance when exposed to heavy metal salts
}

Bukharina I.L., Islamova N.A.

Udmurt State University, Izhevsk, Russia

E-mail: buharin@udmlink.ru

Key message. The effect of inoculation of Cylindrocarpon magnusianum on plants under the action of heavy metal salts was studied. Effective partnership of the fungus and plants was revealed in the conditions most extreme for the life of plants.

Keywords: Cylindrocarpon magnusianum; micromycetes; heavy metals; inoculation

In connection with the search for natural bioregulators and biocontrollers of plant resistance to extreme factors, it is of interest to study the role of root fungi of endophytes in the formation of resistance mechanisms in plants, including the formation of metal resistance, and in relation to particularly dangerous chemical elements for plants. One of the promising micromycetes in this regard is Cylindrocarpon magnusianum Wollenw.

We have studied the effect of inoculation by a culture of $C$. magnusianum fungus on the formation of adaptive reactions of plants to the action of heavy metal salts in the substrate (using the example of a test culture of tomato Solánum lycopérsicum). The experimental scheme included inoculation with a mushroom culture (control population) and mushroom populations previously adapted to different concentrations of heavy metal salts (TM). The inoculated plants were grown in control conditions and on substrates with the introduction of different concentrations of salts of heavy metals (zinc, copper, lead and chromium). Was evaluated the development of fungus infection in the root system of plants and estimation of plant resistance based on pocatella content of nitrates in leaves, biomass and the percentage of dry matter in the aerial part and root system of plants, soderzanie photosynthetic pigments (chlorophyll $a$ and $b$, carotenoids).

The results did not reveal a stimulating effect that increases the resistance of plants to the action of TM salts in the inoculation of plants by the control population of the fungus $C$. magnusianum. However, a significant effect was established when using TM-adapted mushroom populations.

Fungal infection in the roots of plants in all variants of the experiment was well developed.

It is particularly noted that when using non-biogenic chemical elements, adaptive reactions of plants associated with the content of photosynthetic pigments in leaves and the formation of plant biomass were most significantly manifested in the inoculation of plants by adapted populations of the fungus $C$. magnusianum and in further cultivation of plants on substrates with the addition of chromium and lead salts. This fact may indicate the most effective partnership between the $C$. magnusianum fungus and plants in conditions that are extreme for plant life.

This work was supported by the grant of the Russian Foundation for Basic Research "Postgraduate Student" No. 19-34-50037.

\section{Влияние инокуляции корневой системы растений эндофитом Cylindrocarpon magnusianum на показатели растений при воздействии солей тяжелых металлов}

Бухарина И.Л., Исламова Н.А

Удмуртский государственный университет, Ижевск, Россия

\begin{abstract}
Аннотация. Изучено влияние инокуляции Cylindrocarpon magnusianum на растения при действии солей тяжельх металлов. Эффективное партнерство гриба и растений выявлено в условиях наиболее экстремальных для
\end{abstract} жизнедеятельности растений.

Ключевые слова: Cylindrocarpon таgпиsianum; микромицеты; тяжелье металль; инокуляция

В связи с поиском природных биорегуляторов и биоконтроллеров устойчивости растений к экстремальным факторам интерес представляет изучение роли корневых грибов эндофитов в формировании механизмов устойчивости у растений, включая формирование металлресистентности, причем в отношении особо опасных для растений химических элементов. Одним из перспективных микромицетов в этой связи является Cylindrocarpon magnusianum Wollenw.

Нами проведено изучение влияние инокуляции культурой гриба $C$. таgnusianum на формирование адаптивных реакций растений к действию солей тяжелых металлов в субстрате (на примере тестовой культуры томата Solánum lycopérsicum).

Схема эксперимента включала инокуляцию культурой гриба (контрольная популяция) и популяциями гриба, предварительно адаптированными к разным концентрациям солей тяжелых металлов (ТМ). Инокулированные растения выращивались в контрольных условиях и на субстратах с внесением разных концентраций солей тяжелых металлов (цинка, меди, свинца и хрома). Была проведена оценка развития грибной инфекции в корневой системе растений и оценка устойчивости растений на основе покателей содержания нитратов в листьях, биомассы и процентного содержания сухого вещества в надземной части и корневой системе растений, содердания фотосинтетических пигментов (хлорофиллы $a$ и $b$, каротиноиды).

Результаты не выявили стимулирующего эффекта, повышающего устойчивость растений к действию солей ТМ, при инокуляции растений контрольной популяцией гриба $C$. magnusianum. Но значительный эффект установлен при использовании адаптированных к ТМ популяций гриба.

Грибная инфекция в корнях растений во всех вариантах опыта была хорошо развита.

Особо отмечено, что при использовании небиогенных химических элементов адаптивные реакции растений, связанные с содержанием фотосинтетических пигментов в листьях и формированием биомассы растений, наиболее значимо проявились при инокуляции растений адаптированными популяциями гриба $C$. magnusianum и при дальнейшем культивировании растений на субстратах с внесением солей хрома и свинца. Этот факт может свидетельствовать о наиболее эффективном партнерстве гриба $C$. magnusianum и растений в условиях экстремальных для жизнедеятельности растений.

Работа выполнена при поддержке гранта РФФИ "Аспирант" № 19-34-50037. 